\title{
EVALUASI PERUBAHAN TUTUPAN LAHAN MENGGUNAKAN CITRA SATELIT MUTITEMPORAL TAHUN 2009-2011 \\ (Studi Kasus : Muara Kali Porong)
}

Nurul Hidayah, Agung Budi Cahyono

Program Studi Teknik Geomatika FTSP-ITS, Kampus ITS Sukolilo, Surabaya, 60111

Email : nurulday13@geodesy.its.ac.id

\begin{abstract}
Abstrak
Kali Porong merupakan area pembuangan lumpur Sidoarjo untuk mencegah jebolnya tanggul akibat pertambahan volume lumpur secara terus menerus. Kebijakan membuang lumpur ke Kali Porong menimbulkan dampak bagi lingkungan di sekitar Kali Porong. Material lumpur ini tidak hanya mengendap pada sepanjang aliran sungai tetapi juga di daerah muara Kali Porong. Sedimen inilah yang menyebabkan terjadinya pertambahan daratan (reklamasi) hingga terjadi perubahan tutupan lahan di sekitar muara Kali Porong. Area terdampak lumpur yang semakin meluas juga menyebabkan perubahan tutupan lahan.
\end{abstract}

Metode yang digunakan untuk mengevaluasi perubahan tutupan lahan adalah dengan menggunakan teknologi penginderaan jauh yang dapat mencakup wilayah yang luas dengan cepat dan efesien. Data yang digunakan adalah citra satelit ALOS AVNIR-2 tahun 2009 dan 2010 serta SPOT-4 tahun 2011. Metode klasifikasi terbimbing dengan algoritma maximum likehood digunakan untuk mengetahui perubahan tutupan lahan yang terjadi di muara Kali Porong.

Berdasarkan hasil penelitian, didapatkan perubahan luasan tutupan lahan antara tahun 2009 hingga 2011. Pada tahun 2009 hingga 2010, kelas yang mengalami pertambahan luas adalah jalan, lumpur, semak, dan tambak/empang. Sedangkan kelas yang mengalami penurunan luas adalah lahan hutan basah, pemukiman, pertanian, dan sungai. Pada tahun 2010 hingga 2011, kelas yang mengalami pertambahan luas adalah jalan, lahan hutan basah, lumpur, pertanian, semak dan sungai. Sedangkan kelas yang mengalami penurunan luas adalah pemukiman dan tambak/empang. Diantara perubahan luasan tutupan lahan yang terjadi, kelas pemukiman mengalami penurunan tiap tahunnya, dimana sejak tahun 2009 hingga 2010 luasan pemukiman berkurang 364,46 ha dan pada tahun 2010 hingga 2011 luasan pemukiman berkurang 117,49 ha. Sedangkan luas lumpur bertambah sejak tahun 2009 hingga 2010 sebesar 221,66 ha dan 41,91 ha pada tahun 2010 hingga 2011. Penyebab perubahan luas tutupan lahan ini antara lain, meluasnya area lumpur Sidoarjo yang menyebabkan tergenangnya kawasan pemukiman serta persawahan, dampak lingkungan akibat pembuangan lumpur seperti rusaknya tambak karena lumpur yang terus mengalir hingga ke saluran tambak, dan kondisi psikologis masyarakat sekitar semburan yang khawatir untuk tetap tinggal atau bermukim di sekitar lokasi akibat perkembangan semburan lumpur.

Kata Kunci : Penginderaan Jauh, Muara, Tutupan Lahan, ALOS AVNIR-2, SPOT-4

\section{PENDAHULUAN}

\section{Latar Belakang}

Peristiwa lumpur Sidoarjo yang terjadi sejak tahun 2006 menyebabkan tergenangnya kawasan di sekitar pusat semburan di Desa Renokenongo, Kecamatan Porong, Kabupaten Sidoarjo, Jawa Timur, yang meliputi permukiman, persawahan, fasilitas umum, hingga perindustrian. Semburan lumpur panas yang terus keluar hingga saat ini membutuhkan monitoring secara intensif dan multitemporal untuk menghasilkan upaya penanggulangan yang tepat. Saat ini Kali Porong merupakan area pembuangan lumpur untuk mencegah jebolnya tanggul akibat pertambahan volume lumpur secara terus menerus. Kebijakan membuang lumpur ke Kali Porong menimbulkan dampak bagi lingkungan di sekitar Kali Porong. Material lumpur ini tidak hanya mengendap pada sepanjang aliran sungai tetapi juga di daerah muara Kali Porong. Sedimen inilah yang menyebabkan terjadinya pertambahan daratan (reklamasi) hingga terjadi perubahan tutupan lahan di sekitar muara Kali Porong. Area terdampak lumpur yang semakin meluas juga menyebabkan perubahan tutupan lahan. Perubahan tutupan lahan ini berpengaruh terhadap kehidupan masyarakat sekitar yang 
menuntut ketersediaan ruang untuk pemenuhan kebutuhan hidupnya baik perumahan, perindustrian, lahan budidaya dan kegiatan pertanian lainnya yang menimbulkan dampak negatif terhadap sosial ekonomi lingkungan di sekitar lokasi semburan akibat tidak sesuainya fungsi lahan. Oleh karena itu, perlu adanya pemantauan terhadap perubahan tutupan lahan yang terjadi untuk menanggulangi dampak negatif yang ditimbulkan serta untuk acuan dalam menentukan kebijakan lebih lanjut seperti dalam pengembangan wilayah.

Perubahan tutupan lahan yang terjadi dapat diidentifikasi dengan teknologi penginderaan jauh menggunakan citra satelit ALOS (Advanced Land Observing Satellite) dan SPOT-4 (Systeme Probatoire de l'Observation de la Terre). Dengan menggunakan citra satelit ALOS AVNIR-2 tahun 2009, ALOS AVNIR-2 tahun 2010, dan SPOT-4 tahun 2011 dilakukan analisa perubahan tutupan lahan di sekitar muara Kali Porong.

Penelitian ini dapat memberikan informasi terkini mengenai kondisi tutupan lahan di sekitar muara Kali Porong yang dapat dijadikan bahan evaluasi Rencana Tata Ruang Wilayah (RTRW) Kabupaten Sidoarjo untuk mengetahui seberapa besar pengaruh lumpur Sidoarjo terhadap pengembangan wilayah Sidoarjo saat ini dan memprediksi pola pengembangan di sekitar muara Kali Porong untuk beberapa tahun kedepan.

\section{Perumusan Masalah}

Seberapa jauh perubahan tutupan lahan yang terjadi di wilayah muara Kali Porong pada tahun 2009 sampai tahun 2011 dengan membandingkan citra ALOS AVNIR-2 2009, ALOS AVNIR-2 2010, dan SPOT-4 2011.

\section{Batasan Masalah}

Batasan masalah dari penelitian ini sebagai berikut:

1. Citra satelit yang digunakan adalah citra satelit ALOS AVNIR-2 tahun 2009, ALOS AVNIR-2 tahun 2010, dan SPOT-4 tahun 2011.

2. Wilayah penelitian yang digunakan adalah Kecamatan Jabon, Kecamatan Tanggulangin, dan Kecamatan Porong.
3. Analisa perubahan tutupan lahan dilakukan dengan membandingkan citra ALOS AVNIR-2 tahun 2009, ALOS AVNIR-2 tahun 2010, dan SPOT-4 tahun 2011.

4. Hasil analisa perubahan tutupan lahan disajikan dalam bentuk peta.

\section{Tujuan Penelitian}

Adapun tujuan dari penelitian ini adalah untuk menganalisa perubahan tutupan lahan akibat pembuangan lumpur di muara Kali Porong tahun 2009, 2010, dan 2011 hingga diperoleh informasi terkini terkait perubahan tutupan lahan di muara Kali Porong serta daerah terdampak lainnya yang berada di Kecamatan Tanggulangin, Kecamatan Jabon, dan Kecamatan Porong.

\section{METODOLOGI PENELITIAN}

\section{Lokasi Penelitian}

Lokasi penelitian ini berada di muara Kali Porong serta lokasi yang terdampak lumpur Sidoarjo, dengan 3 area kecamatan yaitu Kecamatan Tanggulangin, Kecamatan Porong, dan Kecamatan Jabon.

\section{Data Dan Peralatan}

\section{- Data}

Data yang digunakan dalam penelitian ini adalah:

1. Data citra satelit ALOS AVNIR-2 tahun 2009 , ALOS AVNIR-2 tahun 2010, dan SPOT-4 tahun 2011 wilayah muara Kali Porong Sidoarjo.

2. Peta Topografi (RBI) Kabupaten Sidoarjo skala 1:25.000 tahun 1999.

3. Landsat Ortho

4. RTRW Kabupaten Sidoarjo.

5. Koordinat sample dari lapangan

\section{- Peralatan}

Peralatan yang digunakan dalam penelitian ini adalah:

1. Perangkat Keras (Hardware)

a. GPS Navigasi Garmin

2. Perangkat Lunak (Software)
a. Program Pengolah Citra ER-Mapper 7.0
b. ArcView 3.3
c. Autodesk Land Desktop 2004 
d. Matlab 7.0.1

e. Microsoft Office 2007

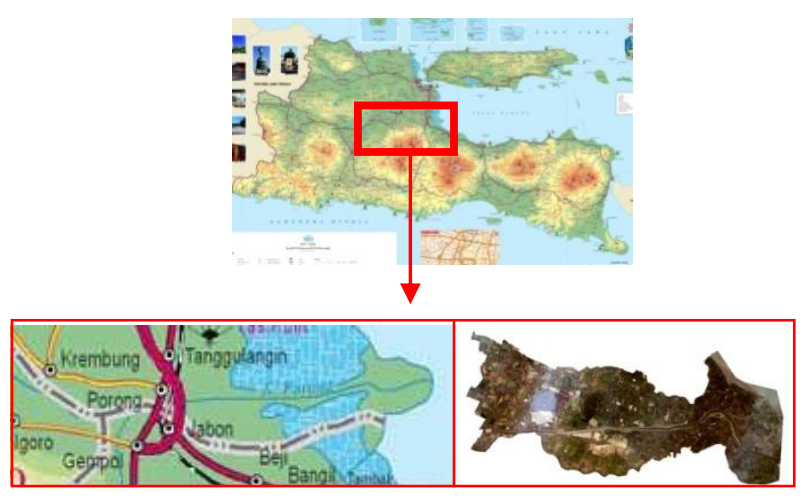

Gambar 2.1 Lokasi Penelitian

Diagram Alir Pengolahan Data

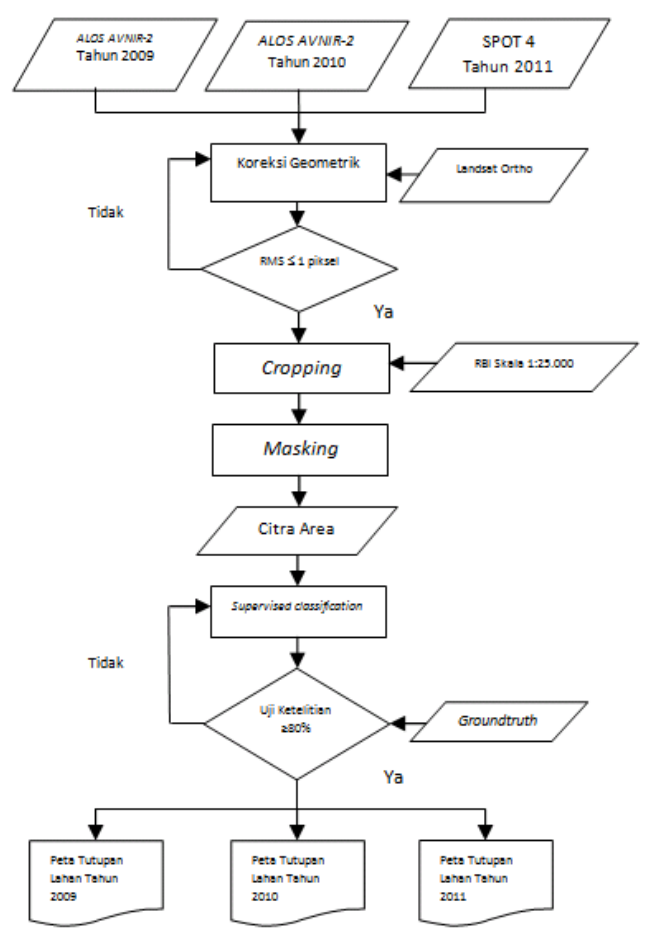

Gambar 2.2 Diagram Tahap Pengolahan Data

\section{HASIL DAN PEMBAHASAN}

\section{Koreksi Geometrik}

Koreksi geometrik memenuhi toleransi jika RMSe kurang dari 1 piksel (Purwadhi, 2001) dan SoF mendekati nol (Abidin, 2000). Berikut tabel hasil koreksi geometrik:

Berdasarkan tabel 1, koreksi pada ketiga citra dianggap memenuhi toleransi Karena RMSe kurang dari 1 piksel dan SoF mendekati nol.
Tabel 1. Hasil Koreksi Geometrik

\begin{tabular}{cccc}
\hline Citra & $\begin{array}{c}\text { Total } \\
\text { RMSe }\end{array}$ & $\begin{array}{c}\text { Rata- } \\
\text { Rata } \\
\text { RMSe }\end{array}$ & SoF \\
\hline $\begin{array}{c}\text { ALOS AVNIR-2 } \\
\text { Tahun 2009 }\end{array}$ & 0,47 & 0,039 & 0,00098814 \\
$\begin{array}{c}\text { ALOS AVNIR-2 } \\
\text { Tahun 2010 } \\
\text { SPOT-4 Tahun } \\
\text { 2011 }\end{array}$ & 0,55 & 0,046 & 0,00051282 \\
\hline
\end{tabular}

\section{Pemotongan Citra (cropping)}

Pemotongan citra dilakukan berdasarkan batas administratif tiga Kecamatan yaitu Kecamatan Porong, Kecamatan Jabon, Kecamatan Tanggulangin. Berikut hasil pemotongan ketiga citra :

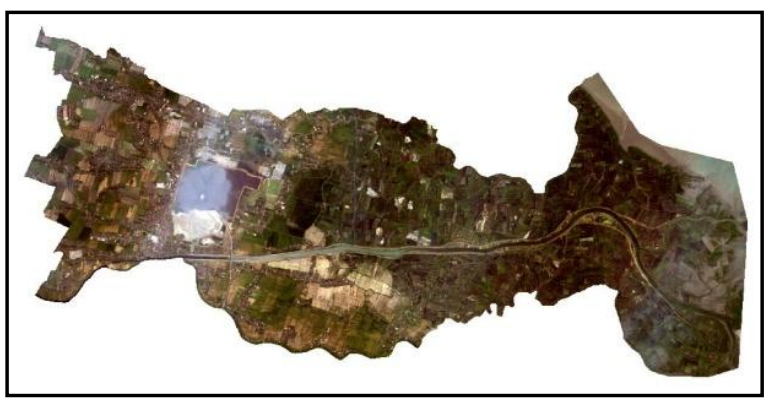

(a)

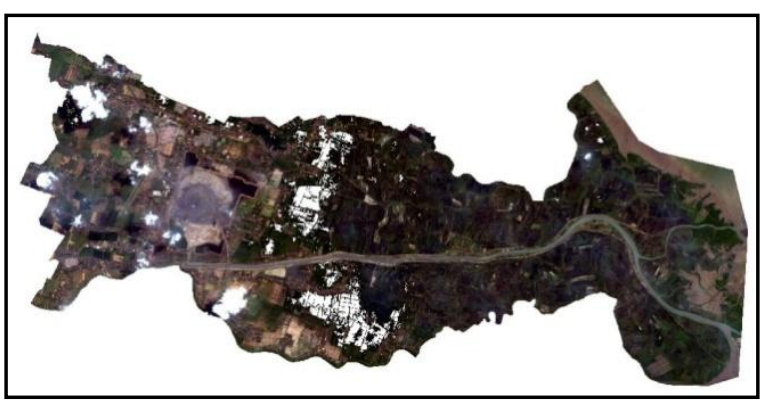

(b)

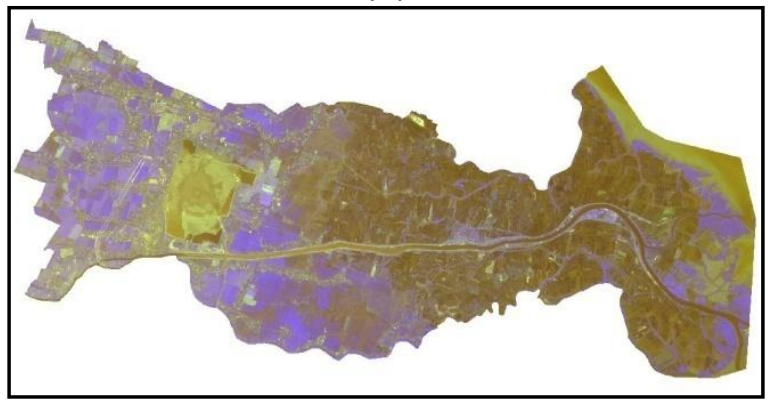

(c)

Gambar 3. Hasil Pemotongan Citra ALOS AVNIR-2 Tahun 2009 (a), ALOS AVNIR-2 Tahun 2010 (b), SPOT4 Tahun 2011 (c) 
Pemotongan citra dengan masking dilakukan untuk memisahkan citra daratan dan lautan. Berikut hasil pemotongan masking:

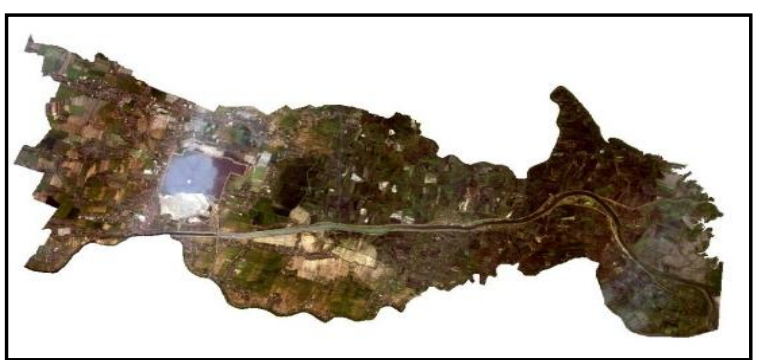

(a)

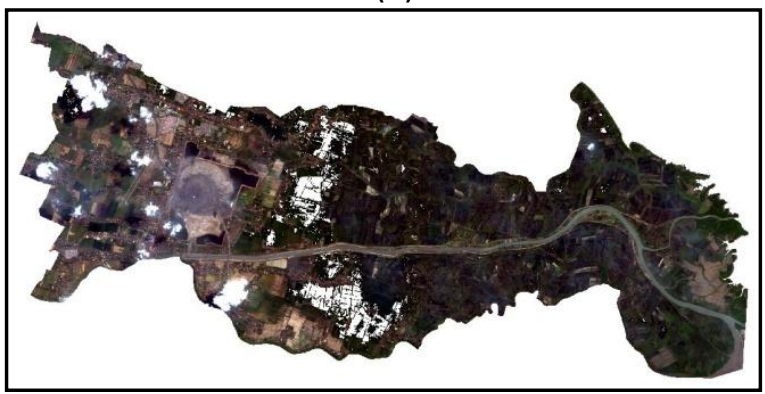

(b)

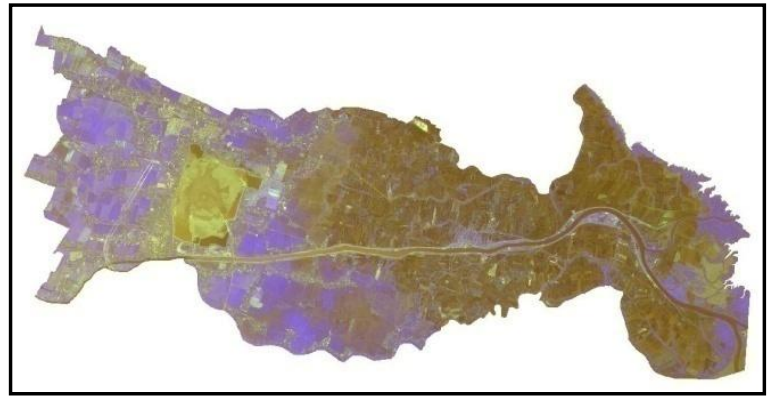

(c)

Gambar 3. Hasil Pemotongan Masking Citra ALOS AVNIR-2 Tahun 2009 (a), ALOS AVNIR-2 Tahun 2010 (b), SPOT-4 Tahun 2011 (c)

\section{Klasifikasi}

Klasifikasi dilakukan dengan delapan kelas, yaitu: jalan, lahan hutan basah, lumpur, pemukiman, pertanian, semak, sungai, dan tambak / empang. Klasifikasi ini mengacu pada paper USGS berjudul "A Land Use And Land Cover classification System For Use With Remote Sensor Data" yang ditulis oleh Anderson (2001) dan disesuaikan dengan tujuan penelitian. Berikut ini hasil klasifikasi tutupan lahan tahun $2009-2011$ :

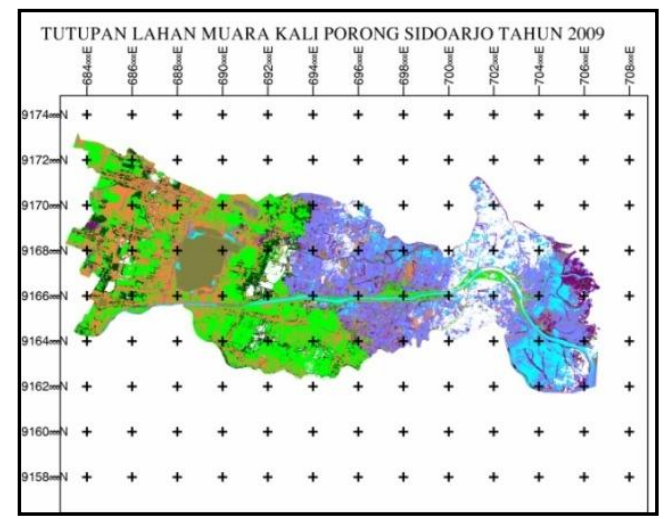

(a)

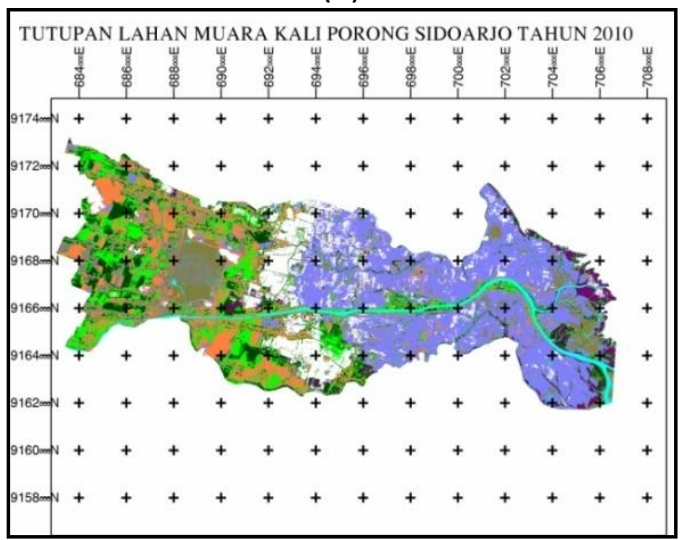

(b)

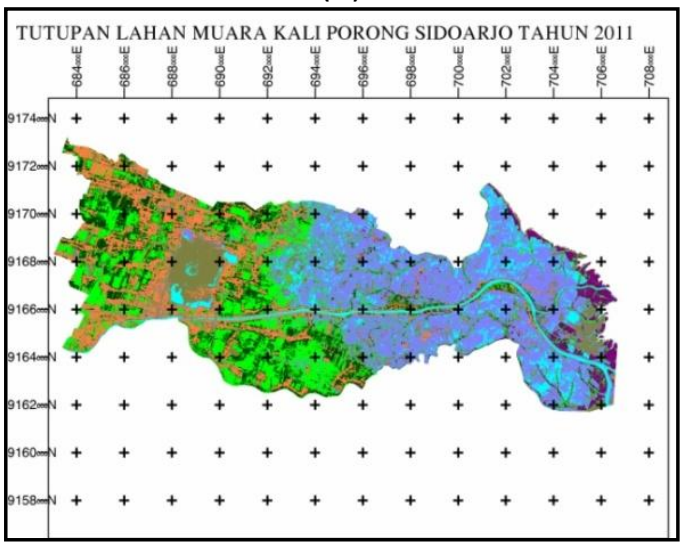

(c)

Gambar 4. Hasil Klasifikasi Tutupan Lahan tahun 2009 (a), 2010 (b), 2011 (c)

\section{Uji Ketelitian Klasifikasi}

Uji ketelitian dilakukan dengan perhitungan confusion matrix, dimana titik-titik hasil klasifikasi pada setiap kelas tutupan lahan dibandingkan dengan koordinat sebenarnya dilapangan. Pada uji ketelitian hasil klasifikasi tahun 2009 diperoleh hasil ketelitian sebesar $82 \%$ sehingga klasifikasi dianggap benar. 


\section{Analisa Perubahan Tutupan Lahan}

Perubahan luasan tutupan lahan pada umumnya berdampak pada sosial dan ekonomi masyarakat di tiga Kecamatan yaitu Kecamatan Porong, Kecamatan Jabon, dan Kecamatan Tanggulangin. Data RTRW digunakan sebagai data pembanding dari data hasil klasifikasi.

Terjadinya perbedaan luasan antara RTRW dan tutupan lahan pada kelas lahan hutan basah disebabkan adanya konservasi serta pengembangan mangrove di pesisir Kecamatan Jabon. Pada kelas pemukiman perbedaan disebabkan karena tuntutan masyarakat akan kebutuhan perumahan. Sedangkan pada kelas tambak/empang perbedaan disebabkan rusaknya tambak akibat lumpur yang terus mengalir hingga saluran tambak.

Dari tabel perubahan tutupan lahan tahun 2009 hingga 2010 di atas, dapat diketahui bahwa kelas lahan hutan basah, pemukiman, pertanian, dan sungai mengalami penurunan luas masing- masing sebesar 403,46 ha, 364,46 ha, 1272,72 ha, dan 592,03 ha. Penurunan tersebut disebabkan oleh volume semburan lumpur yang terus bertambah sehingga kawasan lumpur semakin meluas dan kawasan tergenang semakin banyak. Upaya pembuangan lumpur ke Kali Porong dapat menyebabkan penumpukan sedimentasi baik di sepanjang Kali Porong atau di muara Kali Porong yang mempengaruhi pendangkalan sungai.

Pada tahun 2009 hingga 2010 kelas yang mengalami pertambahan luas adalah jalan, lumpur (221,66 ha), semak (773,44 ha), dan tambak/empang (1226,62 ha). Dari pengamatan BPLS (Badan Penanggulangan Lumpur Sidoarjo) diketahui debit keluarnya lumpur diperkirakan $80.000 \mathrm{~m} 3 /$ hari pada tahun 2009, 40.0000 $\mathrm{m} 3 /$ hari pada tahun 2010, dan $10.000 \mathrm{~m} 3 /$ hari pada tahun 2011. Dari data tersebut dapat diketahui pertambahan volume lumpur pada tahun 2009 mencapai $19.200 .000 \mathrm{m3}$, pada tahun 2010 mencapai $14.600 .000 \mathrm{~m} 3$ dan pada tahun 2011 mencapai $3.650 .000 \mathrm{~m} 3$.

Pada tahun 2010 hingga 2011, kelas yang mengalami penurunan luas adalah pemukiman dan tambak/empang sedangkan kelas yang lain mengalami pertambahan luas. Dari data BPLS diatas, volume lumpur pada tahun 2010 -2011 terus mengalami penambahan meskipun tidak sebanyak tahun 2009-2010. Luasan lahan hutan basah mengalami peningkatan karena mulai dibudidayakannya mangrove di pesisir pantai serta di Pulau Sarinah yang merupakan pulau buatan dari pengumpulan lumpur hasil pengerukan muara Kali Porong. Kelas pemukiman pada tahun 2009 mengalami penurunan lebih kecil dibandingkan pada tahun 2010 dikarenakan sektor perekonomian Sidoarjo pada umumnya mulai membaik. Pada kelas tambak/empang mengalami penurunan disebabkan banyaknya tambak yang rusak akibat lumpur yang terus mengalir hingga ke saluran tambak.

\section{Groundtruth}

Groundtruth dilakukan dengan metode insitu yaitu mengambil sampel dan mencatat nya secara langsung dilapangan. Data groundtruth digunakan untuk membandingkan hasil klasifikasi.

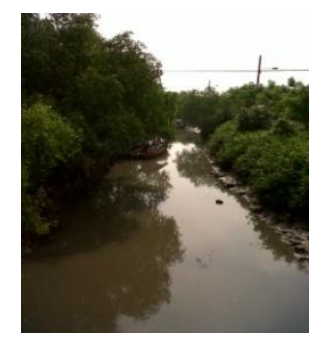

(a)

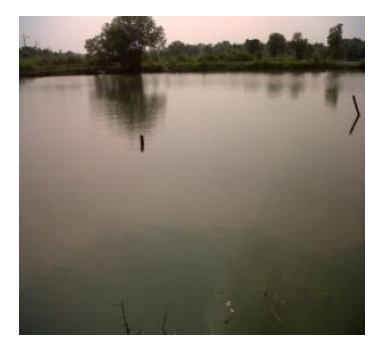

(b)

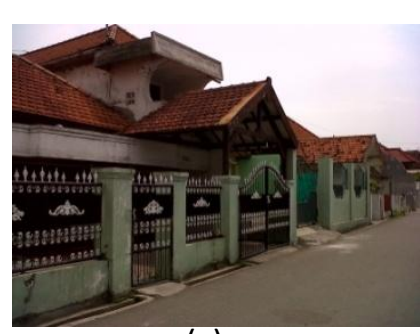

(c)
Gambar 5. Area Sampel Sungai (a), Tambak/Empang (b), Pemukiman (c)

\section{KESIMPULAN}

Selama tahun 2009-2010 terjadi peningkatan luasan tutupan lahan pada kelas lumpur $(221,66$ ha), jalan $(433,82$ ha), semak $(773,44$ ha), dan tambak/empang (1226,62 ha). Sedangkan luasan tutupan lahan yang mengalami penurunan adalah kelas pemukiman (364,46 ha), lahan hutan basah $(403,46$ ha), pertanian $(1272,72$ ha), dan sungai (592,06 ha). 
Pada tahun 2010-2011 kelas yang mengalami pertambahan luasan antara lain: jalan (53,48 ha), lahan hutan basah (187,09 ha), lumpur (41,91 ha), pertanian $(1118,56 \mathrm{ha})$, semak (113,4 ha) dan sungai $(700,22$ ha). Sedangkan kelas yang mengalami penurunan luasan adalah pemukiman (117,49 ha) dan tambak/empang $(625,15 \mathrm{ha})$.

Penyebab perubahan luas tutupan lahan ini antara lain: meluasnya area lumpur Sidoarjo yang menyebabkan tergenangnya kawasan pemukiman serta persawahan, dampak lingkungan akibat pembuangan lumpur seperti rusaknya tambak karena lumpur yang terus mengalir hingga ke saluran tambak, dan kondisi psikologis masyarakat sekitar semburan yang khawatir untuk tetap tinggal atau bermukim di sekitar lokasi akibat perkembangan semburan lumpur.

\section{SARAN}

Berdasarkan hasil analisa yang dilakukan, terjadinya perubahan tutupan lahan setiap tahunnya mengarah pada kerusakan lingkungan akibat semburan lumpur Sidoarjo, hendaknya pemerintah daerah setempat dan semua elemen masyarakat melakukan penataan kembali dan menjaga keseimbangan ekosistem untuk kehidupan masyarakat berdasarkan prediksi volume lumpur mendatang.

\section{DAFTAR PUSTAKA}

Anderson, J.R., Ernest E.H., John T.R., dan Richard W. 1976. A Land Use and Land Cover Classification System For Use With Remote
Sensor Data. Washington: United States Printing Office.

Campbell, J.B. 1987. Introduction to Remote Sensimg. New York : The Guilford Express.

Danoedoro, P. 1996. Pengolahan Citra Digital : Teori dan Aplikasi dalam Bidang Penginderaan Jauh. Yogyakarta : Fakultas Geografi Universitas Gadjah Mada.

Geoimage,

2010.Satellite,<http://www.geoimage.com .au/geoimage/index.php?page=SPOT1-4>. dikunjungi pada tanggal 8 Oktober 2011, jam 21.00.

Japan Aerospace Exploration Agency, March. 2008. ALOS AVNIR-2 Data Users Handbook, $<$ http://www.eorc.jaxa.jp/ALOS AVNIR2/en/doc/fdata/ALOS AVNIR2_HB_RevC_EN.pdf>. dikunjungi pada tanggal 9 Oktober 2011, jam 20.00.

Jensen, J.R. 1986. Introductory to Digital Image Processing. A. Remote Sensing Perspective. Second Edition. New Jersey : Prentice Hall.

Lillesand, T.M., dan R.W. Kiefer. 1994. Penginderaan Jauh dan Interpretasi Citra. Alih Bahasa: Dulbahri. Yogyakarta : Gajah Mada University Press.

Moko, G.I. 2011. Evaluasi Perubahan Tutupan Lahan Wilayah Perairan Pesisir Surabaya Timur Sidoarjo Dengan Menggunakan Citra Satelit Multitemporal. Surabaya : Teknik Geomatika FTSP-ITS

Purwadhi, F. 2001. Interpretasi Citra Digital. Jakarta : Grasindo.

Susilowati, D. 2003. Penerapan Metode Penginderaan Jauh Dan Sistem Informasi Geografis Untuk Analisa Perubahan Penggunaan Lahan (Studi Kasus: Wilayah Kali Surabaya). Surabaya : Teknik Geomatika FTSP-ITS. 


\section{LAMPIRAN}

Tabel 2. Matriks Uji Klasifikasi

\begin{tabular}{|c|c|c|c|c|c|c|c|c|c|c|c|c|c|c|c|}
\hline & & \multirow[b]{2}{*}{ Kelas } & \multicolumn{8}{|c|}{ Hasil Klasifikasi } & \multicolumn{5}{|c|}{ Perhitungan Akurasi } \\
\hline & & & 1 & 2 & 3 & 4 & 5 & 6 & 7 & 8 & $\mathbf{a}$ & b & c (\%) & d & e \\
\hline \multirow{8}{*}{ 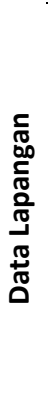 } & 1 & Jalan & 6 & 0 & 0 & 1 & 0 & 0 & 0 & 0 & 6 & 7 & 85,7 & 1 & 2 \\
\hline & 2 & $\begin{array}{l}\text { Lahan Hutan } \\
\text { Basah }\end{array}$ & 0 & 1 & 0 & 0 & 0 & 0 & 0 & 0 & 1 & 1 & 100,0 & 0 & 0 \\
\hline & 3 & Lumpur & 0 & 0 & 5 & 0 & 0 & 0 & 0 & 0 & 5 & 5 & 100,0 & 0 & 0 \\
\hline & 4 & Pemukiman & 0 & 0 & 0 & 3 & 0 & 0 & 0 & 0 & 3 & 3 & 100,0 & 0 & 1 \\
\hline & 5 & Pertanian & 1 & 0 & 0 & 0 & 3 & 0 & 0 & 0 & 3 & 4 & 75,0 & 1 & 2 \\
\hline & 6 & Semak & 0 & 0 & 0 & 0 & 2 & 1 & 0 & 0 & 1 & 3 & 33,3 & 2 & 0 \\
\hline & 7 & Sungai & 1 & 0 & 0 & 0 & 0 & 0 & 2 & 0 & 2 & 3 & 66,7 & 1 & 0 \\
\hline & 8 & $\begin{array}{l}\text { Tambak / } \\
\text { empang }\end{array}$ & 0 & 0 & 0 & 0 & 0 & 0 & 0 & 6 & 6 & 6 & 100,0 & 0 & 0 \\
\hline & & & 8 & 1 & 5 & 4 & 5 & 1 & 2 & 6 & 27 & 32 & & 5 & 5 \\
\hline \multicolumn{4}{|c|}{ Akurasi Keseluruhan (\%) } & & & & & & & & & & \multicolumn{2}{|c|}{84,4} & \\
\hline
\end{tabular}

Tabel 3. RTRW Kabupaten Sidoarjo Tahun 2009

\begin{tabular}{clc}
\hline No. & \multicolumn{1}{c}{ Kelas } & Luas (ha) \\
\hline 1 & Lahan Hutan Basah & 314,21 \\
2 & Pemukiman & 1988,73 \\
3 & Pertanian & 1858,63 \\
4 & Tambak/empang & 5137 \\
\hline
\end{tabular}

Tabel 4. Perubahan Luasan Tutupan Lahan Tahun 2009 - 2010

\begin{tabular}{llcccc}
\hline \multirow{2}{*}{ No } & \multicolumn{1}{c}{ Kelas } & \multicolumn{2}{c}{ Luas (ha) } & \multicolumn{2}{c}{ Perubahan Luas (ha) } \\
& & $\mathbf{2 0 0 9}$ & $\mathbf{2 0 1 0}$ & Berkurang & Bertambah \\
\hline 1 & Jalan & 408,92 & 842,74 & 0 & 433,82 \\
2 & Lahan Hutan Basah & 810,61 & 407,15 & 403,46 & 0 \\
3 & Lumpur & 662,81 & 884,47 & 0 & 221,66 \\
4 & Pemukiman & 2580 & 2215,54 & 364,46 & 0 \\
5 & Pertanian & 3308,69 & 2035,97 & 1272,72 & 0 \\
6 & Semak & 856,28 & 1629,72 & 0 & 773,44 \\
7 & Sungai & 964,85 & 372,82 & 592,03 & 0 \\
8 & Tambak/Empang & 3430,96 & 4697,58 & 0 & 1226,62 \\
\hline
\end{tabular}

Tabel 5. Perubahan Luasan Tutupan Lahan Tahun 2010 - 2011

\begin{tabular}{|c|c|c|c|c|c|}
\hline \multirow{2}{*}{ No. } & \multirow{2}{*}{ Kelas } & \multicolumn{2}{|c|}{ Luas (ha) } & \multicolumn{2}{|c|}{ Perubahan Luas (ha) } \\
\hline & & 2010 & 2011 & Berkurang & Bertambah \\
\hline 1 & Jalan & 842,74 & 896,22 & 0 & 53,48 \\
\hline 2 & Lahan Hutan Basah & 407,15 & 594,24 & 0 & 187,09 \\
\hline 3 & Lumpur & 884,47 & 926,38 & 0 & 41,91 \\
\hline 4 & Pemukiman & 2215,54 & 2098,05 & 117,49 & 0 \\
\hline 5 & Pertanian & 2035,97 & 3154,53 & 0 & 1118,56 \\
\hline 6 & Semak & 1629,72 & 1743,12 & 0 & 113,4 \\
\hline 7 & Sungai & 372,82 & 1073,04 & 0 & 700,22 \\
\hline 8 & Tambak/Empang & 4697,58 & 4072,43 & 625,15 & 0 \\
\hline
\end{tabular}

